\title{
Karakteristik Pertumbuhan dan Hasil Tanaman Brokoli (Brassica oleraceae L. var. italica Plenck) yang Diberikan Green Manure Tithonia diversifolia
}

\author{
Characteristics of Plant Growth and Resullts of Broccoli \\ (Brassica oleracea L. var. Italica Plenck) \\ Given Green Manure Tithonia diversifolia
}

\author{
Hafifah \\ Program Studi Agroekoteknologi, Fakultas Pertanian, Universitas Malikussaleh \\ Kampus Cot Teungku Nie, Reuleut, Muara Batu Aceh Utara 24355, Indonesia \\ Email:fifanago@gmail.com
}

Diterima 20 Januari 2016; Dipublikasi 1 Maret 2016

\begin{abstract}
Abstrak
Penelitian ini bertujuan untuk mengetahui dosis green manure T.diversifolia yang tepat terhadap pertumbuhan dan hasil tanaman brokoli. Penelitian menggunakan rancangan acak kelompok (RAK) dengan 7 perlakuan dosis green manure T.diversifolia yaitu: T0 (Control), T1 (T.diversifolia 0,87 ton/ha setara $25 \mathrm{~kg} \mathrm{~N} /$ ha, T2 (T.diversifolia 1,75 ton/ha setara $50 \mathrm{~kg} \mathrm{~N} /$ ha, T3 (T.diversifolia 2,53 ton/ha setara $75 \mathrm{~kg} \mathrm{~N} /$ ha, T4 (T.diversifolia 3,50 ton/ha setara $100 \mathrm{~kg} \mathrm{~N} / \mathrm{ha}$, T5 (T.diversifolia 4,28 ton/ha setara 125 $\mathrm{kg} \mathrm{N} / \mathrm{ha}$, T6 (T.diversifolia 5,25 ton/ha setara $150 \mathrm{~kg} \mathrm{~N} /$ ha. Data hasil pengamatan dianalisis dengan sidik ragam (ANOVA) dan hasil yang berbeda nyata diuji dengan Uji beda nyata terkecil (BNT) pada taraf $5 \%$. Pengamatan pertumbuhan brokoli diamati pada umur 28 hst, 35 hst, 42 hst, 49 hst, 56 hst dan hasil ditimbang saat tanaman dipanen. Hasil penelitian menunjukkan bahwa pemberian dosis green manure T.diversifolia 5,25 ton/ha setara $150 \mathrm{~kg} \mathrm{~N} /$ ha menghasilkan bobot segar massa bunga sebesar $15.333 \mathrm{~kg} /$ ha setara dengan 15,33 ton $/$ ha.
\end{abstract}

Kata Kunci: brokoli, green manure, Tithonia diversifolia, dosis

\begin{abstract}
This researh aims to determine the dosege appropriate T.diversifolia green manure on growth and yield of broccoli. The researh randomized block design (RBD) with 7 dosage of $\mathrm{T}$. diversifolia green manure namely: T0 (Control), T1 (T. diversifolia 0.87 tonnes / ha equivalent of $25 \mathrm{~kg} \mathrm{~N} / \mathrm{ha}$, T2 (1.75 T. diversifolia 1.75 tonnes / ha equivalent of $50 \mathrm{~kg} \mathrm{~N} /$ ha, T3 ( T. diversifolia 2.53 tonnes / ha, equivalent to $75 \mathrm{~kg} \mathrm{~N} /$ ha, T4 (T. diversifolia 3.50 tonnes / ha equivalent to $100 \mathrm{~kg} \mathrm{~N} /$ ha, T5 (T. diversifolia 4.28 tonnes / ha equivalent of $125 \mathrm{~kg} \mathrm{~N} / \mathrm{ha}$, T6 (T. diversifolia 5.25 tonnes / ha equivalent to $150 \mathrm{~kg} \mathrm{~N} / \mathrm{ha}$. the data were analyzed by analysis of variance (ANOVA) and significantly different results tested by the test least significant difference (LSD) at 5\% level. Observation broccoli growth observed at 28 dap, 35 dap, 42 dap, 49 dap, 56 dap and the results were weighed when the crops are harvested. the results showed that the dosing T. diversifolia green manure 5,25 tons / ha equivalent to $150 \mathrm{~kg} \mathrm{~N} / \mathrm{ha}$ fresh weight mass produce interest at $15333 \mathrm{~kg}$ / ha equivalent to 15.33 tonnes / ha.
\end{abstract}

Key words: broccoli, green manure, Tithonia diversifolia, dose

\section{Pendahuluan}

Brokoli (Brassica oleraceae var. italica plenck) ialah jenis sayuran yang berasal dari daerah subtropis, tetapi saat ini brokoli sudah banyak ditanam di Indonesia, Umumnya brokoli sangat membutuhkan daerah yang beriklim dingin dan suhu udaranya lembab dan dingin. Tanaman brokoli mengandung bermacammacam zat gizi yang sangat bermanfaat bagi 
kesehatan. Zat gizi yang terkandung di dalam brokoli ialah air, protein, lemak, karbohidrat, serat, kalsium, zat besi, vitamin (A, C, E, tiamin, riboflavin, nikotinamide), kalsium, betakaroten, dan glutation (Anonymous, 2005). Brokoli merupakan sumber kalium dan zat sulfur yang baik. Sulfur merupakan prekursor glutation yang berperan sebagai proteksi antioksidan terhadap lapisan dalam kulit lambung (Anonymous, 2009). Selanjutnya Pradnyamitha (2008) melaporkan bahwa dalam brokoli yang segar mengandung sulfur yang sangat bermanfaat untuk kesehatan dan mencegah kanker.

Budidaya brokoli secara organik akan melindungi ekosistem dari kerusakan sehingga bisa tercipta sistem pertanian yang berkelanjutan (sustainable agriculture). Sistim pertanian organik relatif murah dan mudah untuk dilakukan serta lebih hemat, aman dan sehat untuk dikonsumsi. Suryanto (2003) melaporkan bahwa sistim pertanian organik sangat berhubungan dengan rotasi tanaman, residu tanaman, kotoran hewan, green manure, pupuk dari batuan alam, tanaman legume, budidaya secara mekanik dan pengendalian hama secara biologis untuk mengelola kesuburan dan produktifitas tanah.

T. diversifolia merupakan tanaman perdu, termasuk dalam famili Asteraceaae yang biasanya tumbuh liar atau ditanam sebagai tanaman pagar. Akhir-akhir ini tanaman ini digunakan sebagai sumber green manure, mulai dikenal dan dimanfaatkan sebagai sumber hara tanaman untuk meningkatkan ketersediaan nutrisi yang digunakan pada tanaman padi di Asia, tanaman jagung dan sayuran (Nyasimi et al., 1997). Palm et al. (1997) melaporkan bahwa Tithonia merupakan salah satu alternatif sumber green manure yang potensial untuk meningkatkan nutrisi tanah. Daun kering $\mathrm{T}$. diversifolia mengandung $3,17 \% \mathrm{~N}, 0,3 \% \mathrm{P}$, $3,22 \% \mathrm{~K}, 2,0 \% \mathrm{Ca}$ dan $0,3 \% \mathrm{Mg}$ (Nyasimi et al., 1997). Pangkasan segar mengandung 3,5\% N, $0,37 \%$ P, dan $4,1 \%$ K. Pelepasan N terjadi setelah 1 minggu dan $\mathrm{P}$ setelah 2 minggu setelah biomasa dimasukan dalam tanah (Jama et al., 2000). Pratikno (2001) menyebutkan T. diversifolia mempunyai kualitas bahan pangkasan yang tinggi dengan kandungan Corganik $45,90 \%, \mathrm{~N}$ total $5,31 \% \mathrm{C} / \mathrm{N}$ rasio $8,68, \mathrm{P}$ total $0,47 \%$, lignin 5,32\% dan Polifenol 2,08\%.

Berdasarkan hal tersebut diatas maka penulis tertarik melakukan penelitian dosis green manure $\mathrm{T}$. diversifolia terhadap pertumbuhan dan hasil tanaman brokoli.

Penlitian ini bertujuan untuk mendapatkan karakteristik pertumbuhan dan hasil tanaman brokoli serta mendapatkan dosis green manure $\mathrm{T}$. diversifolia yang tepat untuk meningkatkan pertumbuhan dan hasil tanaman brokoli.

\section{Bahan dan Metode}

Penelitian lapangan dilakukan di Kebun Percobaan Cangar Universitas Brawijaya,Desa Sumber Brantas, Kecamatan Bumiaji, Kota Madya Batu. Ketinggian tempat 1600 di atas permukaan laut, suhu rata-rata $220 \mathrm{C}$, kelembaban udara 85\%, jenis tanah Andisol.

Bahan-bahan yang digunakan dalam penelitian ini adalah benih brokoli vareitas F-1 Royal Green dari Chia Tai Seed Co.Ltd dan green $\mathrm{T}$. diversifolia. Kandungan $\mathrm{N} \mathrm{T}$. diversifolia $4,82 \%$ dan $0,52 \% \mathrm{~N}$ tanah lokasi penelitian.

Green manure $T$. diversifolia segar dicacah kira-kira $4 \mathrm{~cm}$. Aplikasi dilakukan satu minggu sebelum tanam dengan cara menyebar diatas bedengan dengan $20 \mathrm{~cm}$, kemudian ditutup kembali dengan tanah (dibenam) dan dosis sesuai perlakuan. Ukuran petak pernelitian $6 \mathrm{~m} \times 1 \mathrm{~m}$, jarak antara petak $0,50 \mathrm{~m}$ dan jarak antar ulangan $0,70 \mathrm{~m}$, jarak tanam $50 \mathrm{~cm} \times 60$ $\mathrm{cm}$, jarak antar baris $50 \mathrm{~cm}$ dan dalam baris 60 $\mathrm{cm}$.

Metode yang digunakan ialah Rancangan Acak Kelompok (RAK) sederhana dengan 7 perlakuan dan 3 ulangan yang terdiri dari: T0 (Control), T1 (T.diversifolia 0,87 ton/ha setara $25 \mathrm{~kg} \mathrm{~N} / \mathrm{ha}, \mathrm{T} 2$ (T.diversifolia 1,75 ton/ha setara $50 \mathrm{~kg} \mathrm{~N} / \mathrm{ha}, \mathrm{T} 3$ (T.diversifolia 2,53 ton/ha setara $75 \mathrm{~kg} \mathrm{~N} / \mathrm{ha}$, T4 (T.diversifolia 3,50 ton/ha setara $100 \mathrm{~kg} \mathrm{~N} / \mathrm{ha}, \mathrm{T} 5$ (T.diversifolia 4,28 ton/ha setara $125 \mathrm{~kg} \mathrm{~N} / \mathrm{ha}, \mathrm{T} 6$ (T.diversifolia 5,25 ton/ha setara $150 \mathrm{~kg} \mathrm{~N} / \mathrm{ha}$. Sedangkan untuk dosis dihitung berdasarkan kebutuhan $\mathrm{N}$ untuk tanaman brokoli dan kandungan $\mathrm{N}$ pada green manure T. diversifolia.

Parameter-parameter yang diamati adalah : panjang batang, diameter batang dan luas daun di amati pada umur 28 hst, 35 hst, 42 hst, 49 hst, 56 hst. umur berbunga, umur panen, bobot segar total tanaman dan bobot segar massa bunga dari per tanaman di konversi ke dalam luasan petak dengan rumus : 
$\mathrm{BP}=\mathrm{BT} \times \mathrm{JP} / 1000$

$\mathrm{BH}=10000 \mathrm{~m} 2 / \mathrm{LP} \times \mathrm{BP}$

Dimana:

BP (bobot segar massa bunga per petak)

BT (bobot segar massa bunga per tanaman)

JP (jumlah populasi tanaman per petak)

BT (bobot segar massa bunga per hektar)

LP ( luasan petek)

Data hasil pengamatan dianalisis dengan sidik ragam (ANOVA) dan hasil yang berbeda nyata diuji dengan Uji beda nyata terkecil (BNT) pada taraf $5 \%$.

\section{Hasil dan Pembahasan}

\section{A. Hasil}

\section{Panjang Batang}

Hasil analisis ragam menunjukkan bahwa terdapat perbedaan sangat nyata perlakuan dosis green manure $\mathrm{T}$. diversifolia terhadap panjang batang pada semua umur pengamatan (Tabel 1).

Tabel 1. Rerata panjang batang tanaman brokoli pada perlakuan dosis green manure T. diversifolia.

\begin{tabular}{crcccc}
\hline \multirow{2}{*}{ Perlakuan } & \multicolumn{5}{c}{ Panjang batang $(\mathrm{cm})$ pada umur ... } \\
\cline { 2 - 6 } & $28 \mathrm{hst}$ & $35 \mathrm{hst}$ & $42 \mathrm{hst}$ & $49 \mathrm{hst}$ & $56 \mathrm{hst}$ \\
\hline T0 & $9,62 \mathrm{a}$ & $11,17 \mathrm{a}$ & $13,21 \mathrm{a}$ & $15,00 \mathrm{a}$ & $17,03 \mathrm{a}$ \\
T1 & $9,75 \mathrm{a}$ & $11,25 \mathrm{a}$ & $13,33 \mathrm{a}$ & $15,63 \mathrm{ab}$ & $17,68 \mathrm{ab}$ \\
T2 & $10,78 \mathrm{~b}$ & $12,25 \mathrm{~b}$ & $14,13 \mathrm{~b}$ & $15,50 \mathrm{ab}$ & $17,38 \mathrm{ab}$ \\
T3 & $10,81 \mathrm{~b}$ & $13,65 \mathrm{c}$ & $14,15 \mathrm{~b}$ & $15,53 \mathrm{ab}$ & $17,40 \mathrm{ab}$ \\
T4 & $13,08 \mathrm{~d}$ & $15,63 \mathrm{~d}$ & $16,00 \mathrm{~d}$ & $19,04 \mathrm{c}$ & $21,13 \mathrm{c}$ \\
T5 & $13,11 \mathrm{~d}$ & $15,65 \mathrm{~d}$ & $16,03 \mathrm{~d}$ & $19,07 \mathrm{c}$ & $21,15 \mathrm{c}$ \\
T6 & $11,88 \mathrm{c}$ & $15,50 \mathrm{~d}$ & $15,08 \mathrm{c}$ & $16,63 \mathrm{~b}$ & $18,33 \mathrm{~b}$ \\
\hline BNT & 0,57 & 0,60 & 0,66 & 1,27 & 1,27 \\
\hline
\end{tabular}

Keterangan: Angka didampingi huruf yang sama pada umur yang sama menunjukkan tidak beda nyata pada uji BNT $5 \%$, hst $=$ hari setelah tanam.

Tabel 1 menunjukkan bahwa pemberian green manure $\mathrm{T}$. diversifolia dosis 3,50 ton/ha setara $100 \mathrm{~kg} \mathrm{~N} / \mathrm{ha}$ dan dosis 4,28 ton/ha setara $125 \mathrm{~kg} \mathrm{~N} / \mathrm{ha}$ menghasilkan panjang batang yang terpanjang pada semua umur. Pemberian green manure T. diversifolia dapat meningkatkan panjang batang.
Hasil analisis ragam menunjukkan bahwa terdapat perbedaan sangat nyata perlakuan dosis green manure T.diversifolia terhadap diameter batang pada semua umur pengamatan (Tabel 2).

\section{Diameter Batang}

Tabel 2. Rerata diameter batang tanaman brokoli pada perlakuan dosis green T. diversifolia.

\begin{tabular}{cccccc}
\hline \multirow{2}{*}{ Perlakuan } & \multicolumn{5}{c}{ Diameter batang $(\mathrm{cm})$ pada umur ... } \\
\cline { 2 - 6 } & $28 \mathrm{hst}$ & $35 \mathrm{hst}$ & $42 \mathrm{hst}$ & $49 \mathrm{hst}$ & $56 \mathrm{hst}$ \\
\hline T0 & $1,84 \mathrm{a}$ & $2,37 \mathrm{a}$ & $3,03 \mathrm{a}$ & $3,29 \mathrm{a}$ & $4,33 \mathrm{a}$ \\
T1 & $2,04 \mathrm{~b}$ & $2,68 \mathrm{~b}$ & $3,42 \mathrm{~b}$ & $3,54 \mathrm{~b}$ & $4,63 \mathrm{~b}$ \\
T2 & $2,13 \mathrm{bc}$ & $2,84 \mathrm{~b}$ & $3,70 \mathrm{c}$ & $3,88 \mathrm{c}$ & $5,13 \mathrm{c}$ \\
T3 & $2,16 \mathrm{c}$ & $3,80 \mathrm{c}$ & $3,73 \mathrm{c}$ & $3,91 \mathrm{c}$ & $5,15 \mathrm{c}$ \\
T4 & $2,70 \mathrm{de}$ & $4,48 \mathrm{e}$ & $4,32 \mathrm{~d}$ & $5,38 \mathrm{e}$ & $6,95 \mathrm{e}$ \\
T5 & $2,73 \mathrm{e}$ & $4,50 \mathrm{e}$ & $4,34 \mathrm{~d}$ & $5,40 \mathrm{e}$ & $6,98 \mathrm{e}$ \\
T6 & $2,61 \mathrm{~d}$ & $4,15 \mathrm{~d}$ & $4,18 \mathrm{~d}$ & $4,80 \mathrm{~d}$ & $6,33 \mathrm{~d}$ \\
\hline BNT & 0,10 & 0,21 & 0,19 & 1,21 & 1,21 \\
\hline
\end{tabular}

Keterangan: Angka didampingi huruf yang sama pada umur yang sama menunjukkan tidak beda nyata pada uji BNT $5 \%$, hst $=$ hari setelah tanam. 
Tabel 2 menunjukkan bahwa pemberian green manure $\mathrm{T}$. diversifolia dosis 3,50 ton/ha setara $100 \mathrm{~kg} \mathrm{~N} / \mathrm{ha}$ dan dosis 4,28 ton/ha setara $125 \mathrm{~kg} \mathrm{~N} / \mathrm{ha}$ menghasilkan diameter batang yang terbesar pada semua umur.

\section{Luas Daun}

Hasil analisis ragam menunjukkan bahwa tidak terdapat beda sangat nyata perlakuan dosis green manure $T$. diversifolia pada semua umur terhadap luas daun (Tabel 3).

Tabel 3. Rerata luas daun tanaman brokoli pada perlakuan dosis green manure T. diversifolia

\begin{tabular}{cccccc}
\hline \multirow{2}{*}{ Perlakuan } & \multicolumn{5}{c}{ Luas daun $(\mathrm{cm} 2)$ pada umur ... } \\
\cline { 2 - 6 } & $28 \mathrm{hst}$ & $35 \mathrm{hst}$ & $42 \mathrm{hst}$ & $49 \mathrm{hst}$ & $56 \mathrm{hst}$ \\
\hline T0 & $488,95 \mathrm{a}$ & $742,45 \mathrm{a}$ & $1022,98 \mathrm{a}$ & $1360,91 \mathrm{a}$ & $2039,12 \mathrm{a}$ \\
T1 & $572,24 \mathrm{~b}$ & $916,30 \mathrm{~b}$ & $1284,79 \mathrm{~b}$ & $1517,58 \mathrm{~b}$ & $2151,27 \mathrm{a}$ \\
T2 & $645,84 \mathrm{c}$ & $943,16 \mathrm{~b}$ & $1401,85 \mathrm{c}$ & $1557,25 \mathrm{~b}$ & $2296,34 \mathrm{~b}$ \\
T3 & $645,87 \mathrm{c}$ & $1409,67 \mathrm{c}$ & $1401,87 \mathrm{c}$ & $1557,28 \mathrm{~b}$ & $2296,36 \mathrm{~b}$ \\
T4 & $739,12 \mathrm{~d}$ & $1813,18 \mathrm{e}$ & $1872,68 \mathrm{e}$ & $2342,70 \mathrm{~d}$ & $3580,74 \mathrm{~d}$ \\
T5 & $739,15 \mathrm{~d}$ & $1813,21 \mathrm{e}$ & $1872,70 \mathrm{e}$ & $2342,72 \mathrm{~d}$ & $3580,77 \mathrm{~d}$ \\
T6 & $838,64 \mathrm{e}$ & $1648,41 \mathrm{~d}$ & $1665,60 \mathrm{~d}$ & $1921,16 \mathrm{c}$ & $2885,03 \mathrm{c}$ \\
\hline BNT & 60,58 & 64,72 & 59,01 & 73,73 & 114,91 \\
\hline
\end{tabular}

Keterangan: Angka didampingi huruf yang sama pada umur yang sama menunjukkan tidak beda nyata pada uji BNT 5\%, hst $=$ hari setelah tanam.

Tabel 3 menunjukkan bahwa pemberian green manure $\mathrm{T}$. diversifolia dosis 3,50 ton/ha setara $100 \mathrm{~kg} \mathrm{~N} / \mathrm{ha}$ dan dosis 4,28 ton/ha setara $125 \mathrm{~kg} \mathrm{~N} / \mathrm{ha}$ menghasilkan luas daun yang terbesar pada umur 35 hst, 42 hst, 49 hst, 56 hst.

\section{Umur Berbunga}

Hasil analisis ragam menunjukkan bahwa terdapat perbedaan sangat nyata perlakuan dosis green manure T.diversifolia terhadap umur berbunga (Gambar 1).

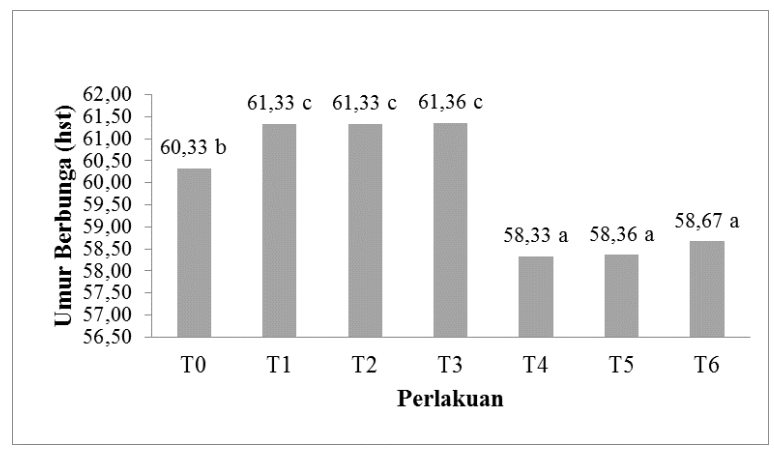

Keterangan: Angka didampingi huruf yang sama pada umur yang sama menunjukkan tidak beda nyata pada uji BNT 5\%, hst = hari setelah tanam.

Gambar 1. menunjukkan bahwa pemberian green manure $T$. diversifolia dosis 3,50 ton/ha setara $100 \mathrm{~kg} \mathrm{~N} / \mathrm{ha}$, dosis 4,28 ton/ha setara $125 \mathrm{~kg} \mathrm{~N} /$ ha dan dosis 5,25 ton/ha setara
$150 \mathrm{~kg} \mathrm{~N} / \mathrm{ha}$ menghasilkan umur berbunga tercepat.

\section{Umur Panen}

Hasil analisis ragam menunjukkan bahwa terdapat beda sangat nyata perlakuan dosis green manure T.diversifolia terhadap umur panen (Gambar 2).

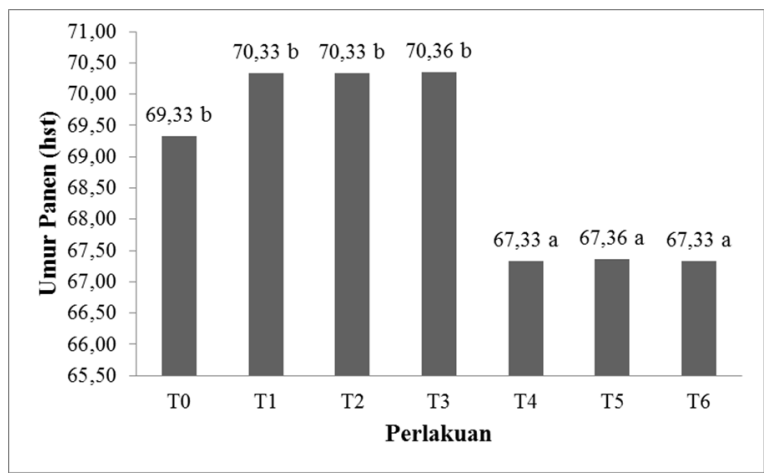

Keterangan: Angka didampingi huruf yang sama pada umur yang sama menunjukkan tidak beda nyata pada uji BNT 5\%, hst = hari setelah tanam.

Gambar 2. menunjukkan bahwa pemberian green manure $\mathrm{T}$. diversifolia dosis 3,50 ton/ha setara $100 \mathrm{~kg} \mathrm{~N} / \mathrm{ha}$, dosis 4,28 ton/ha setara $125 \mathrm{~kg} \mathrm{~N} /$ ha dan dosis 5,25 ton/ha setara $150 \mathrm{~kg} \mathrm{~N} / \mathrm{ha}$ menghasilkan umur panen tercepat. 
Bobot Segar Total Tanaman dan Bobot Segar Massa bunga
Hasil analisis ragam menunjukkan bahwa terdapat beda sangat nyata antara perlakuan dosis green manure $\mathrm{T}$. diversifolia terhadap bobot segar total tanaman dan bobot segar massa bunga (Tabel 5).

Tabel 5. Rerata bobot segar total tanaman dan bobot segar massa bunga tanaman brokoli pada perlakuan dosis green manure $\mathrm{T}$. diversifolia.

\begin{tabular}{ccccc}
\hline Perlakuan & $\begin{array}{c}\text { BSTT } \\
(\mathrm{g})\end{array}$ & $\begin{array}{c}\text { BSMB } \\
(\mathrm{g})\end{array}$ & $\begin{array}{c}\text { BSMB/petak } \\
(\mathrm{Kg})\end{array}$ & $\begin{array}{c}\text { BSMB/ha } \\
(\mathrm{ton})\end{array}$ \\
\hline T0 & $825,00 \mathrm{a}$ & $280,83 \mathrm{a}$ & $11233,33 \mathrm{a}$ & $11,23 \mathrm{a}$ \\
T1 & $903,33 \mathrm{ab}$ & $285,83 \mathrm{ab}$ & $11433,33 \mathrm{ab}$ & $11,43 \mathrm{ab}$ \\
T2 & $980,00 \mathrm{bc}$ & $333,33 \mathrm{bc}$ & $13333,33 \mathrm{~b}$ & $13,33 \mathrm{bc}$ \\
T3 & $980,03 \mathrm{bc}$ & $333,36 \mathrm{bc}$ & $13333,36 \mathrm{bc}$ & $13,36 \mathrm{bc}$ \\
T4 & $1065,00 \mathrm{~cd}$ & $357,50 \mathrm{c}$ & $14300,00 \mathrm{c}$ & $14,30 \mathrm{c}$ \\
T5 & $1065,03 \mathrm{~cd}$ & $357,53 \mathrm{c}$ & $14300,03 \mathrm{c}$ & $14,33 \mathrm{c}$ \\
T6 & $1125,00 \mathrm{~d}$ & $383,33 \mathrm{c}$ & $15333,33 \mathrm{~d}$ & $15,33 \mathrm{c}$ \\
\hline BNT & 132,58 & 43,61 & 20053,52 & 2,05 \\
\hline
\end{tabular}

Keterangan : Angka didampingi huruf yang sama pada umur yang sama menunjukkan tidak beda nyata pada uji BNT $5 \%$, hst $=$ hari setelah tanam, $\mathrm{BSTT}=$ bobot segar total tanaman, $\mathrm{BSMB}=$ bobot segar massa bunga

Tabel 5 menunjukkan bahwa pemberian green manure $\mathrm{T}$. diversifolia dosis $100 \mathrm{~kg} \mathrm{~N}$ ha1 , dosis $125 \mathrm{~kg} \mathrm{~N}$ ha-1 dan dosis $150 \mathrm{~kg} \mathrm{~N}$ ha-1 menghasilkan bobot segar total tanaman dan bobot segar massa bunga tercepat.

\section{B. Pembahasan}

Hasil penelitian terhadap karakter pertumbuhan tanaman brokoli dengan pemberian green manure T. deversifolia menunjukkan pengaruh yang sangat nyata pada setiap komponen pertumbuhan tanaman brokoli. Penambahan dosis green manure T. deversifolia menunjukkan peningkatan panjang batang, diameter batang, luas daun, umur berbunga dan umur panen. Pengaruh ini memiliki keterkaitan dengan potensi ketersediaan unsur hara melalui perbaikan sifat fisik dan sifat kimia tanah yang akhirnya akan mempengaruhi pertumbuhan tanaman brokoli sebagai akibat pemberian green manure $\mathrm{T}$. deversifolia merupakan sumber bahan organik. Hal ini karena bahan organik merupakan perekat butiran lepas, sumber hara tanaman dan sumber energi dari sebagian besar organisme tanah, disamping itu pemberian pupuk organik dapat meningkatkan daya larut unsur $\mathrm{P}$, $\mathrm{K}$, Cadan $\mathrm{Mg}$, meningkatkan Corganik, kapasitas tukar kation, dan daya serap air (Hakim et al., 1986).

Pemberian green manure $T$. deversifolia dapat memperbaiki atau meningkatkan kesuburan pada tanah dibandingkan dengan pupuk anorganik. Hal ini karena green manure T. deversifolia mempunyai beberapa kelebihan dibandingkan pupuk anorganik, selain proses pelepasan hara secara bertahap, juga dalam pupuk organik terkandung beberapa bahan lainnya yang dapat memperbaiki kesuburan tanah. Hal ini sama dengan pernyataan oleh Sanchez (1992) bahwa keunggulan pemberian pupuk organik dibandingkan pupuk anorganik adalah meningkatkan kandungan tanah akan karbon organik, nitrogen organik, $\mathrm{P}, \mathrm{K}$, dan $\mathrm{Ca}$, sehingga mengakibatkan kenaikan $\mathrm{pH}$ yang nyata. Lebih lanjut Syekhfani (1997) menyatakan bahwa pupuk organik sering digunakan dalam ameliorasi kesuburan tanah untuk memperbaiki sifat fisika, kimia dan biologi tanah, meskipun untuk pemupukan yang bertujuan meningkatkan produksi dapat dilakukan, tapi masih dibutuhkan dalam jumlah besar. Dengan kemampuan T. deversifolia menyimpan air dapat menambah kelembaban tanah sebagai media tanam, juga akan mempengaruhi pertumbuhan tanaman. Atmojo (2003), mengemukakan bahwa penambahan bahan organik akan meningkatkan kemampuan menahan air sehingga mampu menyediakan air dalam tanah untuk pertumbuhan tanaman.

Hasil penelitian menunjukkan pemberian green manure $\mathrm{T}$. diversifolia dosis 3,50 ton/ha setara $100 \mathrm{~kg} \mathrm{~N} / \mathrm{ha}$ dan dosis 4,28 ton/ha setara $125 \mathrm{~kg} \mathrm{~N} /$ ha dapat menghasilkan panjang batang, diameter batang dan luas daun terbaik. Umur berbunga dan umur panen tercepat ditemukan 
pada dosis 3,50 ton/ha setara $100 \mathrm{~kg} \mathrm{~N} / \mathrm{ha}$, dosis 4,28 ton/ha setara $125 \mathrm{~kg} \mathrm{~N} / \mathrm{ha}$ dan dosis 5,25 ton/ha setara $150 \mathrm{~kg} \mathrm{~N} / \mathrm{ha}$. Bobot segar total tanaman dan bobot segar massa bunga juga ditemukan dosis 3,50 ton/ha setara $100 \mathrm{~kg} \mathrm{~N} / \mathrm{ha}$, dosis 4,28 ton/ha setara $125 \mathrm{~kg} \mathrm{~N} / \mathrm{ha}$ dan dosis 5,25 ton/ha setara $150 \mathrm{~kg} \mathrm{~N} / \mathrm{ha}$. Hal tersebut sejalan dengan hasil penelitian Olabode et al. (2007) diperoleh fakta bahwa peningkatan luas daun lebih tinggi secara signifikan $(P<0,05)$, dari pada kontrol dan pupuk anorganik. Lebih lanjut hasil penelitian Adejumo et al. (2011) juga memperoleh fakta bahwa pemberian $T$. diversifolia meningkatkan pertumbuhan vegetatif jagung secara progresif 3 - 12 minggu setelah tanam kecuali pada tanaman kontrol dan pupuk anorganik. Hasil penelitian Hutomo et al. (2015) bahwa pemberian pupuk hijau Tithonia diversifolia dapat meningkatkan komponen pertumbuhan tanaman jagung.

Green manure T. diversifolia dosis 5,25 ton/ha setara $150 \mathrm{~kg} \mathrm{~N} / \mathrm{ha}$ menghasilkan bobot segar massa bunga sebesar $15333 \mathrm{~kg} / \mathrm{ha}$ setara dengan 15.33 ton/ha. Hal tersebut sejalan dengan hasil penelitian Suryanto (1999) diperoleh fakta bahwa penggunaan pupuk Urea dosis $150 \mathrm{~kg}$ $\mathrm{N} / \mathrm{ha}$ dapat menghasilkan bobot segar massa bunga brokoli $556.83 \mathrm{~g}$ per tanaman. Lebih lanjut hasil penelitian Jama et al. (2000) diperoleh fakta bahwa pemberian Tithonia yang setara dosis $60 \mathrm{~kg} \mathrm{~N}$ urea tanpa pemakaian pupuk buatan didapat hasil jagung 2,10 ton per ha. Hasil penelitian Yuwono (2003) diperoleh fakta bahwa pemberian biomasa $\mathrm{T}$. diversifolia dosis $160 \mathrm{~kg} \mathrm{~N} / \mathrm{ha}$ memberikan hasil umbi 29.39 ton/ha pada ubi jalar. Hasil penelitian Khadijah (2007) diperoleh fakta bahwa green manure T. diversifolia dosis 7.28 ton/ha menghasilkan bobot polong 10.94 ton ha-1 pada tanaman kacang panjang. Hasil penelitian Dewanti (2005) diperoleh fakta bahwa $T$. diversifolia dengan dosis $175 \mathrm{~kg} \mathrm{~N} / \mathrm{ha}$ merupakan dosis terbaik di dalam meningkatkan bobot segar umbi kentang di bandingkan dengan yang tanpa dipupuk. Hasil penelitian Hutomo et al. (2015) diperoleh fakta bahwa pemberian pupuk hijau Tithonia dosis 10 (ton) per ha dapat meningkatkan hasil tanaman jagung sebesar 9.2 ton/ha.

Hubungan antara dosis dengan bobot segar massa bunga pada pemberian dosis green manure T. diversifolia dapat dilihat pada Gambar 2.

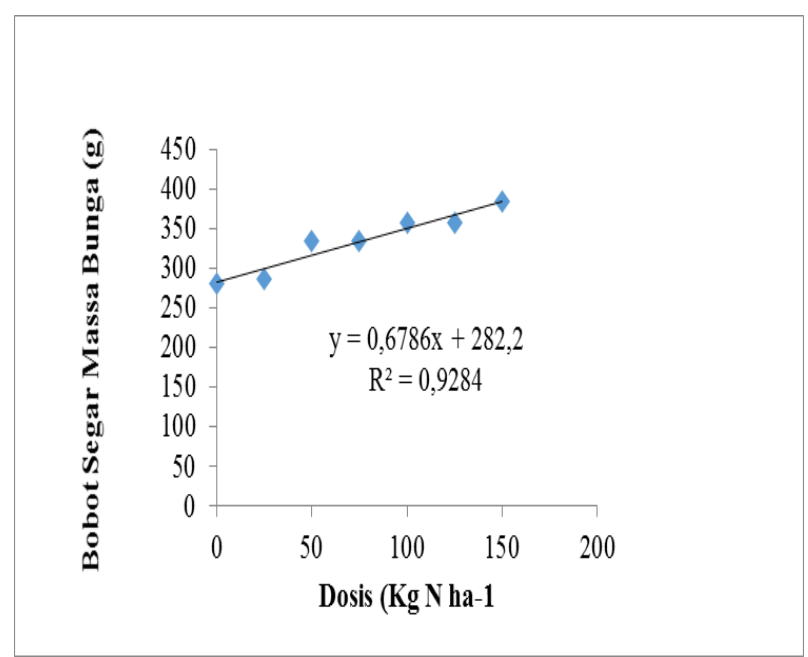

Gambar 2. Hubungan antara dosis green manure $\mathrm{T}$. diversifolia (kg $\mathrm{N}$ ha-1) dengan bobot segar massa bunga (g ha-1)

Gambar 2 menunjukkan persamaan $\mathrm{Y}=$ $0.678 \mathrm{x}+282,2$, bahwa setiap kenaikan dosis $\mathrm{T}$. diversifolia sebesar $1 \mathrm{~kg} \mathrm{~N}$ ha-1 maka akan terjadi kenaikan bobot segar massa bunga sebesar $0,678 \mathrm{~kg}$ ha-1. Hal ini karena green manure $\mathrm{T}$. diversifolia dapat juga memberikan kontribusi hara $\mathrm{P}$ yang cukup terhadap bobot segar mssa bunga. Green manure tersebut bisa meningkatkan ketersediaan $\mathrm{P}$ dan berperan dalam pelepasan $\mathrm{P}$ melalui proses mineralisasi dari kompleks jerapan $\mathrm{Fe}$ dan $\mathrm{Al}$, di mana nutrisi $\mathrm{P}$ sangat penting bagi pertumbuhan vegetatif dan generatif. Menurut pernyataan Stevenson (1986) bahwa hara $\mathrm{P}$ berperan sebagai pentrasfer energi, penyusun protein, koenzim, asam nukleat dan senyawa metabolik dan sangat diperlukan pada saat pembungaan dan pembentukan curd bunga.

\section{Simpulan}

Pemberian dosis green manure $\mathrm{T}$. diversifolia dapat meningkatkan pertumbuhan dan hasil tanaman brokoli. Pertumbuhan dan hasil terbaik ditemukan pada dosis $100 \mathrm{~kg} \mathrm{~N}$ ha1 , dan dosis $125 \mathrm{~kg} \mathrm{~N}$ ha-1. Green manure $\mathrm{T}$. diversifolia dosis 5,25 ton/ha setara $150 \mathrm{~kg} \mathrm{~N} / \mathrm{ha}$ menghasilkan bobot segar massa bunga sebesar $15.333 \mathrm{~kg} /$ ha setara 15,33 ton/ha. 


\section{Daftar Pustaka}

Adejumo, S.A., A.O. Togun, J.A. Adediran and M.B. Ogundiran. 2011. In-Situ Remediation of Heavy Metal Contaminated Soil Using Mexican Sunflower (Tithonia diversifolia) and Cassava Waste Composts. World J. Agric. Sci. 7(2): 224-233.

Anonymous. 2005. Sentra Informasi IPTEK.brokoli. http://www.iptek.net.id/ind/pd tanobat/sea rch.php. Access on : Oktober 7, 2008

Anonymous. 2009. Hidup Damai Bersama Maag, http://ujungpandangekspre.com/view.php. Access on : Januari 1, 2009

Atmojo, W.S. 2003. Peranan Bahan Organik Terhadap Kesuburan Tanah dan Upaya Pengelolaannya. Fakultas Pertanian. Universitas Sebelas Maret. Surakarta.

Dewanti, F.D. 2005. Pengaruh Dosis Paitan dan Kerapatan Tanaman pada Pertumbuhan dan Hasil Tanaman Kentang Varietas Granola Bunga Ungu. Tes. PPS - UB. pp. 95

Hakim, N. 1986. Kemungkinan penggunaan tithonia (Tithonia diversifolia) sebagai sumber bahan organic dan nitrogen. Laporan Penelitian Pemanfaatan Iptek Nuklir (P3IN), Unand. Padang, pp 123.

Hutomo, I.P., Mahfudz dan Laude, S. 2015. Pengaruh Pupuk Hijau Tithonia diversifolia Terhadap Pertumbuhan dan Hasil Tanaman Jagung (Zea mays L.). J. Agrotekbis 3 (4) : 475-481

Jama, B., C. A. Palm, R.J. Buresh, A. Niang, C. Gachengo, G. Nziguheba and B. Amadola. 2000. Tithonia diversifolia as a Green Manure for Soil Fertility Improvement in Westem Kenya: a Review, Agroforestry System. p.201-221 http://www.worldagroforestry.org/eca/dow nlonds/jama. Access on : Oktober 7, 2008.

Khadijah. 2007. Pengaruh Jenis dan Dosis Pupuk Hijau Terhadap Pertumbuhan dan Hasil Kacang Panjang (Vigna sesquipedalis L. Fruwirth).Tes. PPS - UB. pp. 61.

Olabode, O..S., O. Sola, W.B. Akanbi, G.O.
Adesina and P.A. Babajide, 2007. Evaluation of Tithonia diversifolia (Hemsl.) A Gray for Soil Improvement. World J. Agric. Sci., 3 (4): 503-507

Pratikno, H. 2001. Studi Pemanfaatan Berbagai Biomasa Flora untuk Peningkatan Ketersediaan P dan Bahan Organik Tanah Berkapur di Das Brantas Hulu Malang Selatan. Tesis Program Studi Pengelolaan Tanah dan Air, Minat Pengelolaan Tanah, PPS - UB Tess. pp. 95

Palm, A. C., R.J.K. Myers and S.M. Nandwan. 1997. Combined use organic and inorganic nutrient source for soil fertility maintenance and replenishment. Am. Soc. Of Agronomyand Soil Sci. of America.

Pradnyamitha. 2008. Brokoli, Sayuran dan Buah. $\mathrm{http}$ //bayivegetarian.com. Access on : November 19, 2008

Sanchez, P.A. 1992. Sifat dan Pengelolaan Tanah Tropika. ITB. Bandung. p. 146-197

Suryanto, A. 1999. Kajian Bentuk dan Dosis Pupuk Nitrogen pada Tanaman Brokoli (Brassica oleraceae Var. Italica plenck) Habitatat 10(108) : 1- 8

Suryanto, A. T. Himawan dan Sitawati. 2003. Budidaya Sayuran Organik Di Kebun Percobaan Cangar, Kumpulan Makalah Bagpro Pksdm Dikti Depdiknas. FP - UB : 81-86

Stevenson, F. J. 1986. Cycles of Soil Carbon, Nitrogen , Phosphous, Sulfur, and Micronutrients. John Wiley and Sons, New York. pp. 380

Syekhfani, 1997. Hara - Air - Tanah - Tanaman, Jurusan Tanah Fakultas Pertanian Unibraw. pp. 114

Nyasimi, K., A. Niang, B. Amandalo, E. Obonyo and B. Jamal, 1997. Using the wild sunflower, Tithonia, in Kenya. For soil Fertlility and crop yield improvement. International Centre for Research in Agroforestry. Nairobi. p. 12.

Yuwono, M. 2003. Pertumbuhan dan Hasil Ubi Jalar (Ipomea batas L) pada Macam dan Dosis Pupuk Organik Yang Berbeda Terhadap Pupuk Anorganik. Tes. PPS UB.pp.96 